\title{
INTERAKSI SOSIAL WANITA PENGRAJIN BATIK TERHADAP KELUARGA DI DESA BAKARAN KABUPATEN PATI
}

\author{
Arghob Khofya Haqiqi, Ayu Citra Resmi, \\ Bayu Lestiyanto, Yunita Dwi Puspitasari,
}

\author{
Program Studi Tadris IPS IAIN Kudus \\ arghobhaqiqi@gmail.com ayucitra1706@gmail.com \\ bayulesti24@gmail.com yyunita98@gmail.com
}

\begin{abstract}
Most of the workers of the home industry of Bakaran batik industry are housewives. Most of their husbands work as farmers or other jobs outside of agriculture. Most batik craft workers are more engaged by women because batik requires precision, tenacity and high perseverance. The problems that occur among women workers are that they are less able to divide their time aside from make batik every day, also have to complete household chores cook, sweep, care for the house and care for children, etc. The purpose of this study was to determine the social interactions between women batik craftsmen and their families. The method used is qualitative methods and result obtained by means of field observations, interviews, and literature studies. The results of this study are that social interaction between women batik craftsmen with their families is well and sometimes conflict occur. Women batik craftsmen hold social contacts and communicate well with family members. The form of interaction between batik craftsmen and families is an associative and dissociative interaction. Associative because there is cooperation and agreement with the family to achieve
\end{abstract}


the goal. Dissociative because there is a dispute between women batik craftsmen and families that sometimes occur resulting in conflict.

Keywords: social interaction, batik craftsmen, family

Abstrak : Para pekerja usaha indutri rumah kerajinan batik di desa Bakaran Kabupaten Pati sebagian besar juga merupakan ibu rumah tangga. Kebanyakan suami mereka bekerja sebagai petani atau pekerjaan lain diluar pertanian. Kebanyakan para pekerja pengrajin batik lebih ditekuni oleh wanita karena membatik membutuhkan ketelitian, keuletan, dan ketekunan yang tinggi. Permasalahan yang terjadi para wanita pekerja adalah kurang bisa membagi waktu disamping harus membuat batik setiap hari, juga harus menyelesaikan pekerjaan-pekerjaan rumah tangga memasak, menyapu, merawat rumah dan mengasuh anak. Tujuan penelitian adalah mengetahui interaksi sosial antara wanita pengrajin batik di desa Bakaran kaupaten Pati terhadap keluarga. Metode yang digunakan adalah metode kualitatif dan data yang diperoleh dengan cara observasi lapangan, wawancara, dan studi pustaka. Hasil dari penelitian ini adalah interaksi sosial antara wanita pengrajin batik terhadap keluarga berjalan baik dan terkadang terjadi perselisihan. Wanita pengrajin batik saling mengadakan kontak sosial dan berkomunikasi dengan baik sesama anggota keluarga. Bentuk interaksi wanita pengrajin batik dengan keluarga merupakan interaksi yang bersifat asosiatif dan disosiatif. Bersifat asosiatif karena terdapat kerjasama dan kesepakatan dengan keluarga untuk mencapai tujuan. Bersifat disosiatif karena adanya pertikaian antara wanita pengrajin dengan keluarga yang terkadang terjadi sehingga menimbulkan konflik.

Kata Kunci: interaksi sosial, wanita pengrajin batik, keluarga 


\section{A. PENDAHULUAN}

Manusia terlahir sebagai makhluk sosial, kenyataan tersebut menyebabkan manusia tidak akan dapat hidup normal tanpa kehadiran manusia yang lain. Hubungan tersebut dapat dikategorikan sebagai interaksi sosial. Interaksi sosial adalah proses dimana antara individu dengan individu, individu dengan kelompok, atau kelompok dengan kelompok berhubungan satu dengan yang lain (Narwoko, 2004: 20). Ketika orang yang satu bertemu dengan yang lain saat itu juga terjadi interaksi. Kedua orang tersebut bisa saja bertegur sapa, saling menjabat tangan, berbicara dan lain sebagainya. Aktivitas seperti itu termasuk bentu-bentuk interaksi sosial. Aktivitas-aktivitas semacam itu merupakan bentuk-bentuk interaksi sosial. Walaupun orang-orang yang bertemu muka tersebut tidak saling berbicara atau tidak saling menukar tanda-tanda, interaksi sosial telah terjadi, karena masing-masing sadar akan adanya pihak lain yang menyebabkan perubahan-perubahan dalam perasaan maupun syaraf orang-orang yang bersangkutan, yang disebabkan oleh misalnya bau keringat, minyak wangi, suara berjalan, dan sebagainya. Semuanya itu menimbulkan kesan di dalam pikiran seseorang, yang kemudian menentukan tindakan apa yang akan dilakukannya (Soekanto, 2013: 55).

Interaksi sosial juga terjadi di kalangan kelompok pekerja. Baik pekerja laki-laki maupun wanita. Suatu pekerjaan pastilah terjadi interaksi antar sesama kelompoknya. Kelompok pekerja merupakan orang yang menerima upah atas hasil kerjanya. Salah satunya yaitu pekerjaan yang dikerjakan oleh seorang wanita. Wanita berinteraksi sesuai dengan situasi dan kondisinya. Seorang wanita yang belum menikah dan berkarir interaksinya lebih leluasa dengan lingkungannya. Tetapi bila wanita sudah menikah interaksinya lebih terfokus dengan keluarga. Bahkan sebagian wanita mengalami kendala pada karirnya setelah menikah.

Peran wanita merupakan kedudukan (status seorang wanita), yaitu seorang wanita melakukan hak dan kewajibannya sesuai dengan 
kedudukannya. Maka dia menjalankan suatu peran memikul tanggung jawab mengandung, merawat dan mendidik anak-anaknya. Wanita menanamkan rasa cinta terhadap tanggung jawabnya, ketulusan, kesabaran dalam menghadapi segala sesuatu, tanpa kenal lelah dan letih, serta perasaannya yang halus, dan sumber kasih sayang dalam kehidupannya (Jane dan Helen, 1996: 5).

Peran wanita dalam keluarga, yaitu berperan sebagai seorang ibu rumah tangga dan seorang istri. Wanita telah diberikan kedudukan lebih tinggi dalam segala jenis pekerjaan. Wanita dari dahulu sudah bekerja, tetapi baru pada masyarakat industri modernlah mereka berhak memasuki pasaran tenaga kerja sendiri untuk memperoleh pekerjaan tanpa bantuan lelaki. Seorang wanita bekerja untuk menambah tingkat kehidupan keluarganya dan mereka ingin bekerja untuk mencukupi kebutuhanya yang belum terpenuhi. Bekerjanya sang istri meningkatkan pertentangan dalam perkawinan, tetapi tidak mengurangi tingkat kebahagiaan umum di dalam keluarga. Wanita memperoleh lebih banyak kepuasan pribadi dari pekerjaan itu sendiri dan hasilnya (Su'adah, 2005: 208).

Begitu halnya dengan wanita yang bekerja sebagai pengarajin batik di desa Bakaran. Batik Bakaran merupakan salah satu warisan leluhur dan bentuk icon wisata karya seni lukis di desa Bakaran kabupaten Pati. Akan tetapi dari berbagai objek wisata hanya seni lukis batik bakar yang belum mendapat pengelolaan yang maksimal dari pemerintah Kabupaten Pati. Masyarakat setempat yang menguri-uri atau menghidup-hidup tradisi warisan para leluhur. Industri batik sendiri tergolong ke dalam industri kreatif rumahan, dari hasil ekonomi rumahan tersebut mampu memperkokoh pertumbuhan ekonomi yang berada di desa Bakaran (Nurdiantika, 2015: 303). Semakin meningkatnya system kerja industri batik Bakaran sehingga mengakibatkan pembagian kerja pada pengrajin lebih terstruktur. Adapun sistem kerja pada pengrajin batik bakaran meliputi aktivitas produksi, distribusi, dan konsumsi. Sebagian besar aktivitas kerja 
yang mereka lakukan (baik dari pengusaha sampai pada pengrajin) lebih mengutamakan daya serap tenaga kerja manusia sehingga kearifan lokal berbasis masyarakat masih dipertahankan sampai saat ini (Fitranto, 2015: 3).

Pengrajin batik Bakaran didominasi oleh kaum wanita. Peran seorang wanita bukan hanya dilihat dalam kinerjanya dalam bekerja, tetapi wanita mempunyai andil besar dalam membentuk sebuah keluarga yang bermartabat. Wanita bagaikan rumah bagi keluarganya. Wanita yang berperan mengurus rumah tangga, anak, suami, memasak, mengurus rumah dan masih banyak hal lainnya.

Kondisi sebagai ibu rumah tangga dan pengrajin batik Bakaran tidak membuat para wanita tersebut melupakan kewajibannya sebagai makhluk sosial. Dimana setiap manusia harus bersosialisasi dengan manusia lain. Hal ini menarik untuk dibahas bagaimana para wanita pengrajin batik Bakaran ini masih bisa meluangkan waktunya untuk mengurus rumah tangga, keluarga, dan bersosialisasi di masyarakat. Berdasarkan permasalahan tersebut diharapkan dapat memberikan pengetahuan dan gambaran kehidupan para wanita pengarajin batik serta dapat memberi manfaat untuk menumbuhkan motivasi baru bagi peran wanita terhadap keluarga, sehingga terhindar dari perbincangan orang lain yang menyangka interaksi wanita pengrajin pada keluarga terhambat karena lebih terfokus terhadap pekerjaan.

Penelitian ini dilakukan di Desa Bakaran Kulon, Kecamatan Juwana, Kabupaten Pati, Provinsi Jawa Tengah. Ditetapkan berdasarkan pertimbangan pengrajin Batik di desa Bakaran Kulon sebagian besar didominasi oleh wanita dan memiliki potensi untuk dikembangkan. Tenaga kerja pengrajin wanita yang menjadi subyek penelitian, memiliki motivasi kerja tinggi, meskipun interaksi terhadap keluarga terhambat, namun pengrajin batik menunjukkan kesungguhan dan keseriusan untuk mempertahankan pekerjaannya sebagai pembatik hingga kini. 
Penelitian ini menggunakan metode kualitatif. Metode kualitatif merujuk pada cara-cara mempelajari berbagai aspek kualitatif kehidupan sosial yang mencakup ragam dimensi sosial dari tindakan (action) dan keadaan hingga proses, dan peristiwa sebagaimana dimengerti dan berdasarkan konstruksi dan makna yang diorganisasikan oleh dan melalui praktik-praktik sosial. Metode kualitatif digunakan karena dalam pengukuran sebuah rancangan sistem informasi tidak dapat dihitung dengan angka-angka, dapat diukur dari kualitas yang diberikan dan dibentuk oleh sistem.

Untuk mendapatkan data, peneliti melalui beberapa cara antara lain, (1) obseravasi lapangan, yakni pengumpulan data dengan pengamatan langsung dan pencatatan secara sistematis terhadap objek yang akan diteliti, observasi dilakukan secara langsung ke lokasi desa Bakaran; (2) wawancara, yakni pengumpulan data melalui tatap muka dan tanya jawab langsung untuk tujuan suatu tugas tertentu, mencoba mendapakan keterangan atau pendirian secara lisan dari seorang responden, wawancara dilakukan dengan pengrajin batik, tokoh masyarakat, dan instansi/lembaga pengusaha batik; (3) studi pustaka, yakni teknik pengumpulan data dengan cara mencari data yang diperlukan dari berbagai buku, referensi, dan catatan-catatan yang menunjang penyusunan artikel ilmiah ini.

\section{B. PEMBAHASAN}

\section{Pengertian Interaksi Sosial}

Interaksi sosial dapat disebut juga hubungan-hubungan sosial yang bersifat dinamis. Hubungan-hubungan sosial yang dimaksud dapat berupa hubungan antara individu satu dengan individu lainnya, antara kelompok satu dengan kelompok lainnya, maupun antara kelompok dengan individu. Proses interaksi sosial menurut Helbert blumer adalah pada saat manusia bertindak terhadap sesuatu atas dasar makna yang dimiliki sesuatu tersebut atas manusia (Sitorus, 2001: 20). 
Menurut Gillin dan Gillin dalam Soekanto interaksi sosial merupakan hubungan-hubungan sosial yang dinamis yang menyangkut hubungan antar orang perorangan, antara kelompok-kelompok manusia maupun antar orang dengan kelompok. Apabila dua orang maupun lebih itu bertem, interaksi sosial dimulai saat itu. Mereka saling menegur, berjabat tangan, saling berbicara atau mungkin bahkan berkelahi. Aktivitas-aktivitas semacam itu merupakan bentuk-bentuk interaksi sosial (Soekanto, 2005: 12).

Ciri-ciri Interaksi Sosial antara lain:

a. Ada pelaku dengan jumlah lebih dari satu orang

b. Adanya hubungan timbal balik antar pelaku

c. Adanya perbedaan dimensi waktu yang menentukan sifat aksi yang sedang berlangsung

d. Diawali dengan adanya kontak sosial, baik secara langsung atau tidak langsung

e. Mempunyai maksud dan tujuan yang jelas

Suatu interaksi sosial tidak mungkin terjadi apabila tidak memenuhi dua syarat yaitu: adanya kontak sosial, dan adanya komunikasi (Soekato, 2005: 13).

a. Kontak sosial

Kontak sosial berasal dari bahasa latin con atau cum yang berarti menyentuh. Jadi, secara harfiah kontak adalah bersama-sama menyentuh. Kontak sosial merupakan suatu bentuk hubungan sosial antara individu satu dengan individu lain dimana hal itu bersifat langsung, seperti melalui percakapan, maupun berhadapan sebagai wujud aksi dan reaksi. Kontak sosial memiliki dua sifat, yaitu kontak sosial positif dan kontak sosial negatif. Kontak sosial positif adalah kontak sosial yang mengarah pada suatu kerjasama, sedangkan kontak sosial negatif mengarah pada suatu pertentangan.

b. Komunikasi 
Komunikasi adalah proses penyampaian pesan dari seseorang kepada orang lain yang dilakukan secara langsung maupun dengan alat bantu agar orang lain memberikan tanggapan atau tindakan tertentu. Komunikasi menunjukkan seseorang yang memberi tanggapan kepada orang lain (yang berwujud pembicaraan, gerak-gerak badaniyah, atau sikap), perasaan-perasaan apa yang ingin disampaikan orang tersebut. Orang yang bersangkutan kemudian memberi reaksi terhadap perasaan yang ingin disampaikan (Soekato, 2005: 14).

Bentuk-bentuk interaksi sosial yaitu:

a. Proses Asosiatif

1) Kerja Sama (cooperation)

Kerjasama disini dimaksudkan sebagai suatu usaha bersama antara orang perorangan atau kelompok manusia untuk mencapai satu tujuan bersama.

2) Akomodasi (Accomodation)

Istilah akomodasi dipergunakan dalam dua arti yaitu untuk menujuk pada suatu keadaan dan untuk menunjuk pada suatu proses. Akomodasi merujuk pada keadaan dimana adanya suatu keseimbangan dalam interaksi antara orang perorangan maupun antar kelompok yang kaitannya dengan norma sosial dan nilai sosial yang berlaku di dalam masyarakat.

3) Asimilasi (Assimilation)

Asimilasi merupakan proses sosial dalam taraf lanjut. Ia ditandai dengan adanya usaha-usaha mengurangi perbedaan-perbedaan yang terdapat antara individu satu dengan individu lainnya maupun antar kelompok (Sosiologi Tim, 2003: 10).

4) Proses Disosiatif

Proses disosiatif sering disebut sebagai oppotional processes, persis halnya dengan kerjasama, dapat ditemukan dalam masyarakat walaupun bentuk dan arahnya ditentukan oleh kebudayaan dan sistem 
sosial masyarakat yang bersangkutan. Apakah suatu masyarakat lebih menekankan pada salah satu bentuk oposisi atau lebih menghargai kerjasama, hal itu tergantung pada unsur-unsur kebudayaan terutama yang menyangkut sistem nilai, struktur masyarakat dan sistem sosialnya. Proses disosiatif dibedakan dalam tiga bentuk, yaitu:

a) Persaingan (competition)

Adalah suatu proses sosial, dimana individu maupun kelompok tersebut bersaing mencari keuntungan melalui bidang-bidang kehidupan yang pada suatu masa tertentu menjadi pusat perhatian umum dengan cara menarik perhatian publik tanpa mempergunakan kekerasan.

b) Kontravensi

Adalah suatu bentuk proses sosial yang berada antara persaingan dan pertentangan maupun pertikaian.

c) Pertentangan atau pertikaian (conflict)

Merupakan suatu bentuk proses sosial yang terjadi dimana setiap individu maupun kelompok berusaha memenuhi tujuan yang akan dicapai dengan jalan memberikan pertentangan atau menentang pihak lawan dengan cara ancaman atau kekerasan (Sosiologi Tim, 2003: 11).

\section{Definisi Batik Bakaran}

Batik Bakaran merupakan salah satu warisan leluhur dan bentuk icon wisata karya seni lukis di desa Bakaran kabupaten Pati. Akan tetapi dari berbagai objek wisata hanya seni lukis batik bakar yang belum mendapat pengelolaan yang maksimal dari pemerintah Kabupaten Pati. Batik bakaran sendiri di peroleh dari masyarakat desa Bakaran yang menyebut pengrajin batik bakaran, karena penyebutan pengrajin batik desa Bakaran terlalu panjang sehingga diambil nama hasil industri dan tempat industri tersebut di 
buat. Sehingga sekarang kita tahu nama batik bakaran maupun istilah batik batik lain sesuai tempat pembuatannya.

\section{Sekilas Tentang Wanita Pengrajin Batik Bakaran}

Indonesia merupakan negara yang kaya akan suku bangsa dan budaya. Salah satu bentuk budaya adalah batik. Batik merupakan produk budaya asli Indonesia yaitu kesenian gambar di atas kain. Tekniknya memberi warna pada permukaan kain yang tidak tertutup oleh lilin atau malam. Penutupan permukaan kain ini dibantu dengan alat penoreh yang disebut canthing. Teknik pewarnaan dengan cara pencelupan satu hingga tiga kali atau lebih, kemudian lewat proses nglorod untuk menghilangkan malam. Hasil akhir terlihat rangkaian ragam hias yang indah dan menawan. Salah satu sentra batik yang masih eksis keberadaannya hingga kini adalah di Desa Bakaran kecamatan Juwana Kabupaten Pati. Batik Bakaran merupakan salah satu batik tradisional dengan visual ragam hias yang sederhana, termasuk dengan pewarnaan yang hanya menggunakan warna hitam (gelap). Batik Bakaran sekarang mengalami perkembangan dalam motif dan warna, sehingga terlihat mirip Batik Pesisir yang lain.

Tenaga kerja pada usaha home industry kerajinan batik adalah tenaga wanita berasal dari anggota rumah tangga sendiri dan sebagian lagi mengupah pekerja dari tetangga di dekat rumah. Suami mereka bekerja sebagai petani atau pekerjaan lain diluar pertanian. Pekerjaan menjadi pengrajin Batik lebih banyak ditekuni oleh wanita karena membatik memerlukan ketelitian, keuletan, dan ketekunan yang tinggi, dan wanita yang memang cocok melakukan pekerjaan itu. Tenaga kerja laki-laki biasanya hanya membantu saja terutama dalam hal pemasaran. Kegiatan home industry kerajinan Batik memerlukan keahlian khusus, sehingga tidak mudah bagi setiap orang untuk terjun ke dalam usaha tersebut. 


\section{Proses Interaksi Sosial Wanita Pengrajin Batik dengan Keluarga}

Manusia terlahir sebagai makhluk sosial, kenyataan tersebut menyebabkan manusia tidak akan dapat hidup normal tanpa kehadiran manusia yang lain. Hubungan tersebut dapat dikategorikan sebagai interaksi sosial. Interaksi sosial adalah hubungan yang terjadi antara manusia dengan manusia yang lain, baik secara individu maupun dengan kelompok. Interaksi sosial merupakan hubungan-hubungan sosial yang dinamis yang berkaitan dengan orang perorangan, kelompok perkelompok, maupun perorangan terhadap perkelompok ataupun sebaliknya (Muslim, 2013: 485).

Hubungan interaksi sosial antara wanita pengrajin Batik dengan keluarga berjalan baik dan terkadang terjadi perselisihan. Berjalan baik dalam hal ini adalah wanita pengrajin batik mampu mengatur waktunya untuk pekerjaan dan keluarga. Karena usaha membatik ini dikerjakan dirumah, maka dalam bekerjanya santai dan apabila terdapat pesanan dikerjakan sesuai target dan dibantu oleh keluarga. Hal ini senada dengan pernyataan dari seorang pengrajin batik Ninik Sunarsih (52 tahun):

"Batik itu yang penting niat. Kalau udah niat urusan batik sama keluarga berjalan beriringan. Batiknya dirumah soalnya punya sendiri. Jadi batiknya nyantai. Kalau ada pesenan banyak dibantu sama anak juga. Urusan batik lancar hubungan dengan keluarga dan rumah juga lancar. Yang penting niat dan disiplin bagi waktunya."

Dengan demikian wanita pengrajin batik saling mengadakan kontak sosial dan berkomunikasi satu dengan yang lain. Kontak sosial yang dilakukan secara langsung maupun tidak langsung diwujudkan dalam kehidupan rumah tangga dan keluarga. Kontak sosial secara langsung diwujudkan dalam bentuk interaksi wanita pengrajin batik saat sedang membatik dan berkomunikasi bersama keluarga di rumahnya. Sedangkan kontak sosial yang secara tidak langsung diwujudkan dalam bentuk interaksi wanita pengrajin batik yang menerima pesanan kain batik dari pembeli melalui alat komunikasi berupa telepon genggam. Melalui kehidupan rumah 
tangga dan keluarga ini wanita pengrajin batik dapat mudah untuk berkomunikasi dengan sesama anggota keluarga.
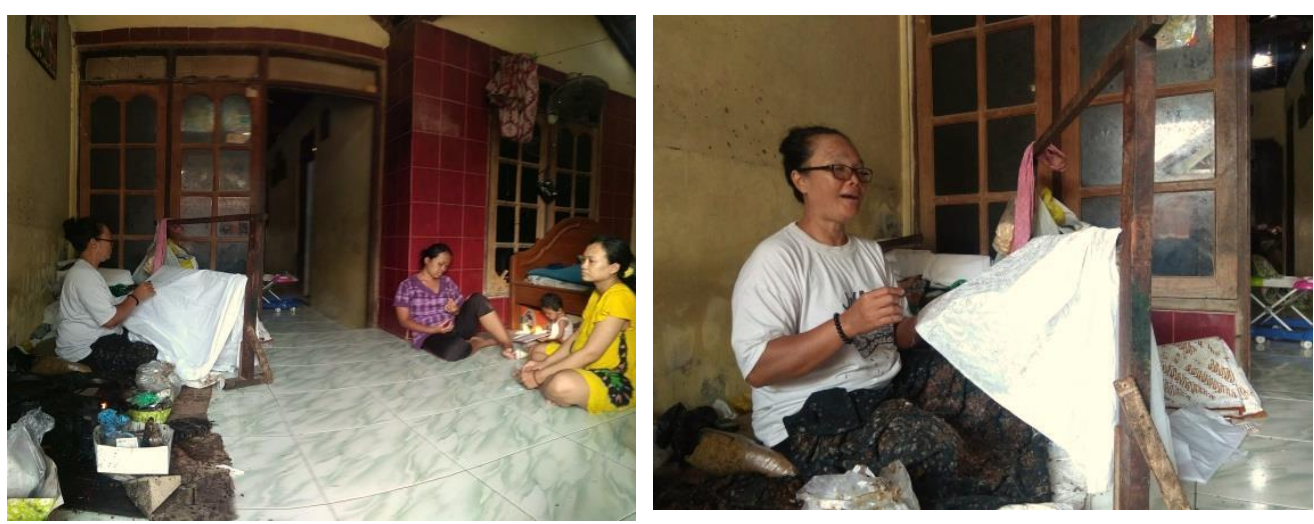

Gambar 1. Interaksi pengrajin batik dirumah dengan keluarga

Bentuk-Bentuk interaksi sosial dapat dibedakan menjadi dua bentuk, yaitu interaksi sosial bersifat asosiatif dan interaksi sosial bersifat disosiatif. Interaksi sosial bersifat asosiatif akan mengacu pada bentuk penyatuan. Interaksi sosial ini terdiri atas beberapa hal yaitu kerja sama (cooperation) contohnya gotong royong membangun masjid dan kerja bakti masyarakat membersihkan lingkungan, akomodasi contohnya musyawarah antara dua kelompok warga yang sedang bertikai agar terjadi kesepakatan dunia, asimilasi contohnya bersikap baik dan tenggang rasa terhadap sesama agar tidak menimbulkan pertengkaran, dan akulturasi. Interaksi sosial bersifat disosiatif ini mengarah pada bentuk pemisahan dan terbagi dalam tiga bentuk yaitu persaingan/kompetisi contohnya persaingan antar pengusaha batik untuk bisa menjual batik lebih banyak ke masyarakat, kontravensi contohnya pertentangan yang terjadi dalam diskusi rapat ataupun debat, dan konflik.

Bentuk interaksi wanita pengrajin batik dengan keluarga merupakan interaksi yang bersifat asosiatif dan disosiatif. Bersifat asosiatif karena adanya hubungan kerjasama yang terbentuk karena para wanita pengrajin ini menyadari bahwa mereka mempunyai kepentingan-kepentingan yang sama terhadap keluarga sehingga sepakat untuk bekerjasama dalam mencapai tujuan bersama denga keluarga. Bersifat disosiatif karena adanya 
pertikaian antara wanita pengrajin dengan keluarga yang terkadang terjadi sehingga menimbulkan konflik. Konflik yang timbul merupakan akibat adanya perbedaan paham dan kepentingan yang sangat mendasar anatar wanita pengrajin dan keluarga, sehingga menimbulkan adanya semacam gap atau jurang pemisah yang mengganjal interaksi sosial di antara mereka yang bertikai tersebut. Namun, konflik tersebut pastinya tidak berlangsung lama sehingga masih bisa diselesaikan dengan hubungan akomodasi antara wanita pengrajin dengan keluarga guna mengurangi, mencegah, atau mengatasi ketegangan dan kekacauan.

Para wanita pengrajin batik di Desa Bakaran berusaha keras untuk mewujudkan peranan-peranannya sebagai seorang wanita dan tidak lupa melaksanakan kewajibannya. Kebanyakan mereka bekerja untuk membantu memenuhi kebutuhan keluarganya dan ada pula sebagai tulang punggung keluarga karena berstatus janda. Dengan waktu yang terbatas, mereka berupaya untuk bisa menjadi seorang istri, ibu dan anggota masyarakat yang baik. Sebelum berangkat kerja mereka menyiapkan makanan untuk suami dan anaknya, mereka juga menyiapkan perlengkapan sekolah anak-anaknya. Wanita pengrajin ini berusaha semampu mereka untuk mengatur waktu bagi keluarga diantara kesibukannya bekerja.

\section{KESIMPULAN}

Proses interaksi sosial wanita pengrajin batik dengan keluarga yaitu dengan menjalankan dan menyeimbangkan peran-perannya. Peran tersebut yaitu wanita sebagai istri, ibu, pengurus rumah tangga dan anggota masyarakat. Wanita pengrajin batik harus menjalin kerja sama dengan keluarga yang baik dan membagi waktu antara pekerjaan dan keluarga. Meski terbatas waktu yang dimiliki, wanita pengrajin harus pandai membagi waktu sehingga proses interaksi sosial berjalan dengan baik dan lancar.

Faktor pendorong dan penghambat interaksi sosial wanita pengrajin batik dengan keluarga yaitu keluarga yang menjadi pembangkit semangat 
untuk menjadikan kehidupan yang lebih baik serta pengertian dan kerja sama dari keluarga. Sedangkan hambatan yang dirasakan adalah cara membagi waktu antara pekerjaan, keluarga dan masyarakat. Hambatan yang lain berupa masalah ekonomi dan faktor kelelahan. 


\section{DAFTAR PUSTAKA}

Fitranto, Achmad Iqbal Galih. 2015. Skripsi: "Budaya Kerja Pada Pengrajin Batik Bakaran (Studi Kasus Di Desa Bakaran Kecamatan Juwana Kabupaten Pati)". Jurusan Sosiologi Dan Antropologi Fakultas Ilmu Sosial Universitas Negeri Semarang.

Jane dan Helen. 1996. Sosiologi Wanita. Jakarta: PT Rineka Cipta.

Muslim, Asrul. 2013. "Interaksi Sosial Dalam Masyarakat Multietnis". Jurnal Diskursus Islam. Vol. 1. Nomor. 3.

Narwoko, J. Dwi. 2004. Sosiologi: Teks Pengantar \& Terapan. Jakarta: Prenada Media.

Nurdiantika, Ema. 2015. Karakteristik Kehidupan Pengrajin Batik (Studi Kasus Di Wilayah Kerajinan Batik Gedog Di Desa Margorejo Kecamatan Kerek Kabupaten Tuban). Swara Bhumi. Vol. 2 Nomor. 2.

Sitorus. 2001. Berkenalan dengan sosiologi Edisi kedua kelas 2 SMA. Bandung: Erlangga.

Soekanto, Soerjono. 2013. Sosiologi Suatu Pengantar. Jakarta: RajaGrafindo Persada.

Sosiologi Tim. 2003. Sosiologi Suatu Pengantar kajian kehidupan masyarakat kelas 1 SMA. Jakarta: Yudhistira.

Su'adah. 2005. Sosiologi Keluarga. Malang: UMM Press.

Wafiroh, Himmah. 2017. Interaksi Sosial Wanita Pengrajin Tenun Ikat Troso Dalam Kegiatan Pemberdayaan Dan Kesejahteraan Keluarga (Pkk). Jurnal IJTIMAIYA. Vol. 1. Nomor. 1. 